\title{
Alezzandrini syndrome
}

\author{
Monica Gupta, ${ }^{1}$ Divya Pande, ${ }^{2}$ S S Lehl, ${ }^{1}$ Atul Sachdev \\ ${ }^{1}$ Department of Medicine, Government Medical College and Hospital, Chandigarh, India; \\ 2Department of Medicine, Government Medical College and Hospital, Mohali, Punjab, India
}

Correspondence toDr Monica Gupta, monicamanish2001@gmail.com

\section{DESCRIPTION}

A 56-year-old diabetic and hypertensive lady presented to us with a history of exertional precordial pain. On physical examination, we came across a very interesting finding of left-sided poliosis (whitening of eyebrow and eyelashes) with a patch of vitiligo over the left eyebrow (figure 1). In addition, there was a history of gradually decreasing visual acuity of the left eye and ipsilateral hypoacusis. A large hyperpigmented macule suggestive of a café-ulait spot was noticed on the ipsilateral side of the neck. According to the history, the skin manifestations were present since 15 years of age and were non-progressive. There was no history of any epilepsy or mental retardation. CT head was essentially normal. Funduscopy was suggestive of mild retinal pigmentary changes in the left eye and no evidence of diabetic retinopathy in the other eye. Audiometry indicated mild ipsilateral sensorineural deafness. This constellation of findings (unilateral skin manifestations, fundus appearance and hypoacusis) befitted the diagnosis of Alezzandrini syndrome. Alezzandrini syndrome is a very rare and distinct clinical syndrome of unknown aetiology first described by Alezzandrini and

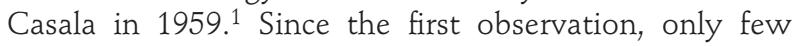
cases have been reported worldwide..$^{2-5}$ This syndrome is characterised by unilateral tapetoretinal (retinal pigment epithelia) degeneration with the ipsilateral appearance of facial vitiligo and poliosis. ${ }^{6}$ A close differential is VogtKoyanagi-Harada syndrome characterised by bilateral decolouration of the skin, eyebrow, eyelashes, alopecia, chronic uveitis and meningoencephalitis. ${ }^{7}$ Our case is unique because here we have demonstrated ipsilateral café-u-lait spot on the neck in combination with the above findings. We could not trace any similar presentation in the medical literature.

Competing interests None.

Patient consent Obtained.

\section{REFERENCES}

1. Casala AM, Alezzandrini AA. Vitiligo, poliosis unilateral con retinitis pigmentaria y hypoacusia. Arch Argent Dermatol 1959;9:449.

2. Hoffman MD, Dudley C. Suspected Alezzandrini's syndrome in a diabetic patient with unilateral retinal detachment and ipsilateral vitiligo and poliosis. $J$ Am Acad Dermatol 1992;26 (3 Pt 2):496-7.

3. Shamsadini S, Meshkat MR, Mozzafarinia K. Bilateral retinal detachment in Alezzandrini's syndrome. Int J Dermatol 1994;33:885-6.

4. Foyaca-Sibat $\mathbf{H}$, Ibañez-Valdés L. Unilateral poliosis and vitiligo: a case report. Internet J Neurol 2004;3.

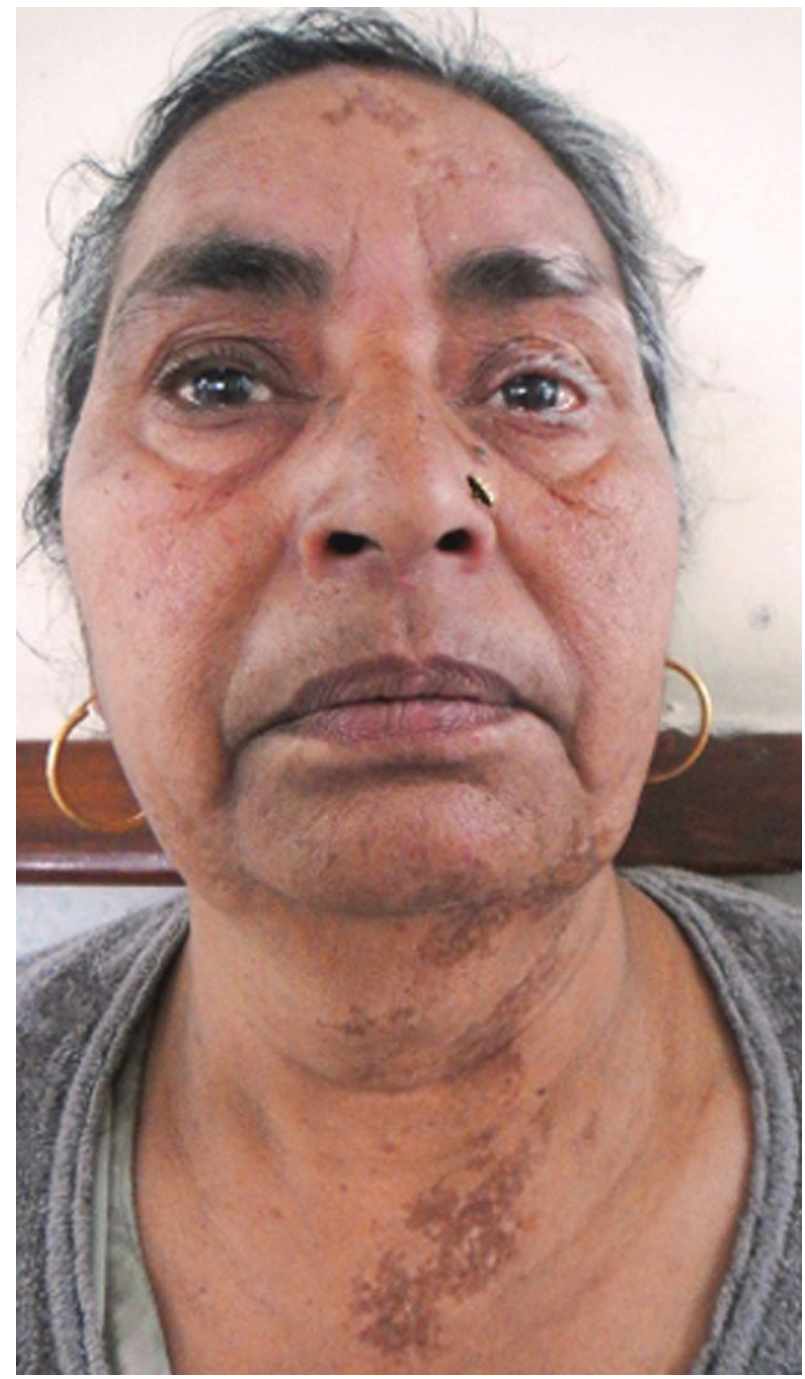

Figure 1 Photograph showing left-sided poliosis and café-u-lait patch.

5. Andrade A, Pithon M. Alezzandrini syndrome: report of a sixth clinical case. Dermatology (Basel) 2011;222:8-9.

6. Alezzandrini AA. Unilateral manifestations of tapeto-retinal degeneration, vitiligo, poliosis, grey hair and hypoacousia. Ophthalmologica 1964;147:409-19.

7. Arnold HL, Odom RB, James WD. Andrew's Diseases of the Skin. Eight edition. Philadelphia, PA: Saunders 1990.

8. Huggins RH, Janusz CA, Schwartz RA. Vitiligo: a sign of systemic disease. Indian J Dermatol Venereol Leprol 2006;72:68-71. 


\section{BMJ Case Reports}

This pdf has been created automatically from the final edited text and images.

Copyright 2011 BMJ Publishing Group. All rights reserved. For permission to reuse any of this content visit http://group.bmj.com/group/rights-licensing/permissions.

BMJ Case Report Fellows may re-use this article for personal use and teaching without any further permission.

Please cite this article as follows (you will need to access the article online to obtain the date of publication).

Gupta M, Pande D, Lehl SS, Sachdev A. Alezzandrini syndrome. BMJ Case Reports 2011;10.1136/bcr.04.2011.4052, date of publication

Become a Fellow of BMJ Case Reports today and you can:

- Submit as many cases as you like

- Enjoy fast sympathetic peer review and rapid publication of accepted articles

- Access all the published articles

- Re-use any of the published material for personal use and teaching without further permission

For information on Institutional Fellowships contact consortiasales@bmjgroup.com

Visit casereports.bmj.com for more articles like this and to become a Fellow 